\title{
PENDEKATAN DALAM ANALISIS WACANA KRITIS
}

\author{
Masitoh $^{1}$ \\ masitohstkipm64@gmail.com
}

\section{Universitas Muhammadiyah Kotabumi}

\begin{abstract}
Critical discourse analysis is a linguistic study that discusses a discourse not only from linguistic elements but also relates it to the context. The main purpose of critical discourse analysis is to open the blurring that is in the discourse. To analyze critical discourse, there were several approaches presented by the experts. First, Norman Fairclough's critical discourse analysis approach explain that discourse activities as a social practice. It was cause a dialectical relationship between social practice and the process of formation of discourse, that is, discourse influences social order and social order affects the discourse. Second, the approach of critical discourse analysis offered by Van Leeuwen were focus on describing social actors in a discourse and explaining how social actors were represented in a text. Third, the critical discourse analysis approach by Van Dijk, namely the social cognitive approach. This approach is not only based on the analysis of language discourse, but also must be seen how the discourse was produced and why such discourse can be obtained. Fourth, the Wodak's critical discourse analysis approach was a historical discourse approach which explains that to conduct an analysis of a discourse was by looking at the historical factors in a discourse. Fifth, Sara Mills's critical discourse analysis approach was a feminist / feminist stylistics perspective that focused on what women appear in a discourse because so far women have always been excluded and were in a bad state and women are not given the opportunity to defend themselves.
\end{abstract}

Keywords: approach, analysis, critical discourse

Abstrak: Analisis wacana kritis adalah studi linguistik yang membahas wacana bukan dari unsur kebahasaan, melainkan juga mengaitkannya dengan konteks. Adapun tujuan utama analisis wacana kritis adalah membuka kesamaran yang ada dalam wacana. Untuk menganalisis wacana kritis, ada beberapa pendekatan yang disampaikan para ahli. Pertama, pendekatan analisis wacana kritis Norman Fairclough menjelaskan bahwa kegiatan berwacana sebagai praktik sosial. Hal ini menyebabkan ada hubungan dialektikal antara praktik sosial dan proses terbentuknya wacana, yaitu wacana mempengaruhi tatanan sosial dan tatanan sosial mempengaruhi wacana. Kedua, pendekatan analisis wacana kritis yang dibuat Van Leeuwen menjelaskan bagaimana orang-orang tertentu dan aktor sosial (social actors) dimunculkan dalam wacana. Ketiga, pendekatan analisis wacana kritis yang dikemukan oleh Van Dijk, yaitu pendekatan kognitif sosial. Pendekatan ini bukan hanya didasarkan pada analisis bahasa wacana, melainkan juga harus dilihat bagaimana wacana tersebut diproduksi dan mengapa dapat diperoleh wacana seperti itu. Keempat, pendekatan analisis wacana kritis Wodak adalah pendekatan wacana historis yang menjelaskan bahwa untuk melakukan analisis pada sebuah wacana dengan cara melihat faktor historis dalam suatu wacana itu. Kelima, pendekatan analisis wacana kritis Sara Mills adalah perspektif feminis/feminist stylistics yang memfokuskan seperti apa perempuan dimunculkan dalam wacana karena selama ini perempuan selalu disingkirkan dan berada dalam keadaan yang tidak baik dan para perempuan itu tidak diberikan kesempatan untuk membela diri. 
Kata Kunci: pendekatan, analisis, wacana kritis

\section{PENDAHULUAN}

Bahasa merupakan salah satu alat komunikasi yang digunakan manusia dan satuan terkecil dari bahasa adalah bunyi yang dikaji dalam fonologi . Selanjutnya adalah kajian morfologi yang membahas proses terbentuk sebuah kata. Satuan bahasa yang ketiga membahas frasa dan kalimat, merupakan kajian sintaksis. Kajian berikutnya adalah kajian semantik yang membahas tentang makna. Terakhir adalah kajian wacana. Ada beberapa pengertian tentang wacana, menurut Alwi, dkk (2003) wacana adalah kalimat yang berkaitan sehingga terbentuklah makna yang serasi dalam kalimat-kalimat itu.

Selanjutnya D. Maingueneau yang dikutip Zaimar (2009) mengatakan bahwa wacana terdiri atas satu kata, satu kalimat maupun banyak kalimat. Wacana dapat juga dipakai istilah ujaran (speech) yang merupakan perpaduan bahasa dan ujaran. Oleh karena itu, wacana dapat berwujud satu kata, satu kalimat, satu paragraf, satu artikel, satu buku, juga dapat berupa beberapa buku, bahkan satu bidang ilmu. Sejalan dengan pendapat di atas, Hamad (2007) menyatakan wacana adalah bahasa yang bermakna yang dapat berbentuk lisan, tulisan, dan simbol. Wujud dari bentuk wacana dapat berupa: (1) teks, berupa pengumuman, karangan, makalah, skripsi roman, dsb; (2) ucapan, berupa percakapan, tanya jawab, dialog, dsb; (3) lakon, berupa drama, sinetron, puisi, atraksi, dsb; (4) ) artefak, berupa bangunan, alat-alat batu, logam , puing, dsb. Oleh karena itu, tidak selamanya wacana berbentuk tulisan di media massa dan di media cetak.

Wacana yang telah dibuat dapat dikritisi dan dianalisis oleh orang lain yang biasa disebut analisis wacana kritis/critical discourse analysis (CDA). Analisis wacana kritis merupakan telaah yang dilakukan seseorang untuk mengkaji lebih dalam makna sesungguhnya yang akan disampaikan oleh pembicara atau penulis dalam tulisan mereka. Yang dianalisis dalam wacana kritis tidak hanya menggambarkan unsur bahasa saja, melainkan juga mengaitkan dengan konteks. Menurut Darma (2009) analisis wacana kritis adalah studi linguistik yang membahas wacana bukan dari unsur kebahasaan, melainkan mengaitkannya dengan konteks. Konteks di sini maksudnya adalah bahasa digunakan sesuai dengan situasi dan kondisi tertentu agar tujuan yang diinginkan tercapai. Dasar teoretis analisis wacana didasarkan pada beberapa perkembangan sejarah dalam filsafat pengetahuan dan teori sosial. Oleh karena itu, faktor histori, sosial, dan ideologi adalah sumber utama dalam kerangka kerja analisis wacana kritis. Analisis wacana kritis 
digunakan untuk menganalisis komunikasi yang penuh dengan kesenjangan, yakni adanya ketidaksetaraan hubungan antarpartisipan, seperti bahasa politik (hubungan antara pemimpin dan staf, dosen dan mahasiswa, serta komunikasi yang berkaitan dengan gender. Tujuan utama analisis wacana kritis adalah membuka kesamaran dalam wacana yang tidak seimbang antarpartisipan wacana

\section{KARAKTERISTIK WACANA KRITIS}

ANALISIS

Dalam analisis wacana kritis (critical discourse analysis), teks bukanlah sesuatu yang bermakna nyata dan menjelaskan sesuatu secara apa adanya. Kebiasaan pribadi dan status sosial pembuat teks akan tergambar pada isi teks. Analisis wacana kritis bukan hanya membahas bahasa dalam suatu teks, melainkan juga menghubungkannya dengan konteks. Konteks di sini maksudnya adalah bahasa yang digunakan sesuai dengan situasi dan kondisi tertentu agar tujuan yang diinginkan tercapai.

Wacana mempengaruhi dan dipengaruhi oleh konteks sosial. Menurut Fairclough (1989) wacana adalah bentuk "praktik sosial" yang berimplikasi adanya dialektika antara bahasa dan kondisi sosial. Linguistik bersifat sosial, maksudnya linguistik tidak dapat melepaskan diri dari pengaruh lingkungan sosialnya. Sementara fenomena sosial juga memiliki sifat linguistik karena aktivitas berbahasa dalam konteks sosial tidak hanya menjadi wujud ekspresi atau refleksi dari proses dan praktik sosial, namun juga merupakan bagian dari proses dan praktik sosial tersebut. Analisis wacana kritis ingin menyingkap bahasa yang digunakan untuk melihat ketidakadilan kekuasaan yang ada di dalam masyarakat.

Adapun karakteristik penting dari analisis wacana kritis menurut Van Dijk yang dikutip Fauzan (2014) berupa tindakan, konteks, histori, kekuasaan, dan ideologi

\section{(1) Tindakan}

Karakter utama dalam analisis wacana kritis yaitu wacana sebagai sebuah tindakan. Artinya, saat berwacana, seseorang akan mengungkap maksudnya lewat bahasa dengan tujuan untuk memberitahukan, memerintah, mempengaruhi, membujuk, dan mengikuti apa yang menjadi keinginannya. Saat seseorang membuat tulisan yang sifatnya menguraikan, dia akan mendeskripsikan wacana tersebut dengan detail sehingga yang membaca akan mendapatkan keterangan yang jelas akan objek yang dideskripsikan. Contoh lain, dosen menegur mahasiswanya agar dapat menaati peraturan yang ada dan tidak mengulangi kesalahan lagi. Dari contoh di atas dapat dijelaskan bahwa pesan yang ingin disampaikan dilakukan secara dua arah, yaitu si penerima pesan dan pembawa pesan sama-sama memposisikan dirinya menjadi pembawa pesan. 
Dari penjelasan di atas, analisis wacana kritis memiliki beberapa konsekuensi. Konsekuensi pertama, wacana memiliki tujuan untuk memberitahukan, memerintah, mempengaruhi, membujuk, mengikuti apa yang menjadi keinginannya,dan sebagainya. Kedua, wacana adalah sesuatu yang dilakukan secara sadar, terencana, dan tertib bukan sesuatu dilakukan dengan tidak sadar dan diluar kontrol.

\section{(2) Konteks}

Analisis wacana kritis selain mempelajari bahasa (teks) itu sendiri, unsur di luar bahasa pun (konteks) harus dipelajari. Menurut Sobur yang dikutip Fauzan (2014) wacana terdiri atas teks dan konteks. Teks bukan hanya kata-kata yang tercetak di lembar kertas, melainkan juga semua jenis ekspresi komunikasi, ucapan, musik, gambar, efek suara, citra, dan sebagainya. Konteks merupakan semua situasi dan hal yang berada di luar teks, seperti partisipan dalam bahasa, situasi saat teks diproduksi, fungsi yang dimaksudkan, dan lain sebagainya. Titik perhatian analisis wacana ialah menggambarkan teks dan konteks secara bersama-sama dalam suatu proses komunikasi. Berdasarkan penjelasan di atas, wacana dapat dibentuk berdasarkan konteks dan dapat ditafsirkan dalam kondisi dan situasi tertentu.

$$
\text { Selanjutnya Eriyanto }
$$
menjelaskan bahwa konteks terbagi menjadi dua, yaitu: (1) berdasarkan jenis kelamin, umur, pendidikan, kelas sosial, etnik, dan agama; (2) setting sosial tertentu, seperti tempat, waktu, posisi pembicara dan pendengar atau lingkungan fisik. Selanjutnya Van Dijk, Fairclough dan Wodak yang dikutip Fauzan (2014) mengatakan bahwa analisis wacana kritis memasukan konteks dalam lingkup latar, situasi, historis, kekuasaan, dan ideologi. Konteks latar dan situasi dalam analisis wacana kritis dapat disamakan dengan konteks situasi, konteks latar belakang pengetahuan, latar belakang pengetahuan apa pun dalam analisis wacana pragmatis. Dengan demikian, para linguis dapat menjelaskan makna yang tersirat dari percakapan yang tersurat.

\section{(3) Historis}

Selain aspek tindakan dan konteks, adalah aspek historis yang perlu diperhitungkan karena wacana tidak dapat dimengerti tanpa menyertakan aspek ini. Misalnya, untuk memahami makna puisi Diponegoro karya Chairil Anwar dan mengungkapkan makna apa yang ingin disampaikan yaitu dengan cara mengungkapkan kapan puisi tersebut diciptakan. Simak potongan bait puisi tersebut.
Di masa pembangunan ini tuan hidup kembali Dan bara kagum menjadi api Di depan sekali tuan menanti Tak gentar lawan banyak seratus kali 
Potongan puisi di atas akan memberi petunjuk tentang sejarah kapan puisi tersebut dibuat oleh pengarangnya. Analisis wacana kritis bukan saja ingin mengetahui satu alasan puisi itu dibuat, melainkan juga banyak hal yang ingin diketahui, yaitu tentang apa, mengapa, di mana dan bila mana puisi tersebut dibuat. Salah satu caranya adalah dengan memanfaatkan aspek historis ini. Hal didukung oleh pendapat Eriyanto (2001), untuk dapat memahami suatu teks, salah satu cara yang digunakan adalah dengan memanfaatkan aspek historis. Teks dapat dipahami apabila kita dapat memberikan aspek historis apa, mengapa, di mana, dan bila mana teks tersebut dibuat, misalnya: di era orde atau waktu perang merebut kemerdekaan, dan sebagainya

\section{(4) Kekuasaan}

Aspek yang yang tidak kalah penting untuk membedakan antara analisis wacana dan analisis wacana kritis, adalah aspek kekuasaan. Eriyanto (2001) mengatakan bahwa wacana yang dibuat dalam bentuk tulisan, ujaran, dan lainnya, tidak terwujud dengan begitu saja secara natural, tetapi hal itu wujud dari pertarungan kekuasaan karena aspek kekuasaan merupakan salah satu bentuk keterkaitan wacana dengan masyarakat. Contohnya: kekuasaan pria terhadap wanita, kekuasaan pimpinan kepada bawahan, dan dosen dengan mahasiswa.
Wacana memandang aspek kekuasaan sebagai suatu kontrol. Kekuasaan berhubungan erat dengan kelompok dominan. Kelompok dominan biasanya akan menguasai kelompok yang lemah atau kelompok yang termarjinalkan. Hal ini dapat terjadi, menurut Van Dijk (dalam Eriyanto, 2001) karena biasanya relasi, ilmu pengetahuan, dan pengalaman kelompok dominan lebih baik dan lebih banyak dari pada kelompok yang lemah atau yang termarjinalkan. Hal ini mengisyaratkan siapa sajakah yang diperkenan untuk berbicara dan siapa yang harus mendengar dan mengiyakan. Misalnya, seorang staf/karyawan diperintahkan atasannya untuk melakukan korupsi. Oleh karena tidak berkuasa untuk menolak, staf/karyawan tersebut harus mendengar dan akan mengiyakan keinginan atasannya.

\section{(5) Ideologi}

Dalam analisis wacana kritis, aspek ideologi merupakan kajian utama. Eriyanto (2001)

meng a tak an

b ahw a

tul is an, ujaran, dan lainnya adalah wujud dari ideologi tertentu. Ideologi dibentuk oleh kelompok dominan yang bertujuan untuk memproduksi ulang dan mengesahkan keberadaan kelompok tersebut. Artinya, kelompok dominan mempengaruhi dan menginformasikan ke khalayak ramai bahwa keberadaan dan kekuatan mereka sudah sah. 
Dengan adanya ideologi akan terbentuk jati diri kelompok yang tidak sama dengan kelompok lain. W a c a n a bukanlah sesuatu yang netral disajikan secara apa adanya karena setiap wacana akan muncul ideologi seseorang untuk mendominasi dan berebut pengaruh. Misalnya dalam wacana argumentasi, dapat dipastikan bahwa teks yang ada merupakan pencerminan dari ideologi seseorang, apakah ideologi orang tersebut kapitalisme, antikapitalisme, individualisme, sosialisme, dan sebagainya.

\section{PENDEKATAN UTAMA DALAM ANALISIS WACANA KRITIS}

Dalam analisis wacana kritis, wacana tidak dipahami sebagai objek studi bahasa semata. Objek studi dalam analisis wacana kritis selain teks juga pada konteks bahasa. Tujuan utama analisis wacana kritis adalah membuka kesamaran dalam wacana yang tidak seimbang antarpartisipan wacana. Di bawah ini akan dijelaskan beberapa pendekatan dalam analisis wacana kritis, adalah sebagai berikut.

\section{(1) Analisisis Wacana Kritis Norman Fairclough (Dialectical-Relational Approach/DRA)}

Pendekatan analisis wacana kritis yang dibuat Norman Fairclough adalah bahwa kegiatan berwacana sebagai praktik sosial. Hal ini menyebabkan ada hubungan yang berkaitan antara praktik sosial dan proses membentuk wacana. Untuk itu, harus dilakukan penelusuran atas konteks produksi teks, konsumsi teks, dan aspek sosial budaya yang mempengaruhi terbentuknya wacana. Fairclough (1989) menjelaskan ada hubungan dialektikal antara praktik sosial dan proses terbentuknya wacana, yaitu wacana mempengaruhi tatanan sosial dan tatanan sosial mempengaruhi wacana. Oleh karena itu, wacana dapat membentuk dan dibentuk oleh masyarakat. Selain itu, wacana juga dapat membentuk dan mengubah pengetahuan, hubungan sosial, dan identitas sosial. Selanjutnya, wacana dibentuk oleh kekuasaan yang berhubungan dengan ideologi. Dengan demikian, pendekatan analisis wacana kritis yang dibuat oleh Fairclough disebut dengan Pendekatan Relasional Dialektikal (Dialectical-Relational Approach/DRA) atau biasa juga disebut dengan pendekatan perubahan sosial.

\section{(2) Analisisis Wacana Kritis Theo Van Leeuwen (Social Actors Approach/SAA)}

Theo van Leeuwen memperkenalkan pendekatan analisis wacana kritis ini untuk menjelaskan bagaimana sebuah kelompok dimunculkan atau disembunyikan. Pendekatan analisis wacana kritis yang dibuat Van Leeuwen menjelaskan bagaimana orangorang tertentu dan aktor sosial (social actors) dimunculkan dalam wacana. 
Bagaimana suatu kelompok yang mendominanasi lebih memegang kendali dan kelompok yang posisinya rendah digambarkan sebagai orang yang tidak baik. Misalnya, kelompok yang dimarjinalkan, seperti: penganguran, PSK, buruh, dan perempuan dianggap kelompok yang tidak memiliki kekuatan dan kekuasaan, mereka juga digambarkan sebagai orang yang tidak berpendidikan, penyakit masyarakat, pengacau, dan selalu berbuat jahat. Citra buruk yang tergambar dalam media kepada kelompok marjinal ini dianggap sebagai kelompok yang tidak baik dan kelompok yang mendominasi menjadi pihak yang terlihat 'dirugikan'.

Berkaitan dengan hal di atas Van Leeuwen yang dikutip Fauzan (2014) memfokus kepada dua hal, yaitu proses eksklusi dan proses inklusi. Proses Eksklusi adalah proses yang menjelaskan bahwa dalam wacana adakah kelompok atau aktor yang tidak ditampilkan dalam pemberitaan, yaitu dengan cara tidak ditampilkan atau menyamarkan dalang utama sehingga pihak yang dirugikanlah yang menjadi pusat perhatian berita. Proses penghilangan dalang utama ini dapat mengubah pikiran masyarakat akan suatu kejadian dan melegalkan posisi pemahaman tertentu. Proses inklusi, yaitu proses memasukkan seseorang atau kelompok tertentu ke dalam wacana, kebalikan dari proses eksklusi. Proses eksklusi dan inklusi merupakan strategi wacana. Proses eksklusi dan inklusi adalah cara menampilkan aktor sosial di dalam wacana dengan memanfaatkan permainan kata atau diksi, kalimat, gaya bahasa, dan cara bercerita tertentu untuk menampilkan aktor sosial yang diinginkan ke dalam sebuah wacana.

\section{(3) Analisisis Wacana Kritis Teun A. Van Dijk (Socio-cognitive Approach/SCA)}

Pendekatan analisis wacana kritis yang dikemukan oleh Van Dijk ini dikenal dengan sebutan "pendekatan kognitif sosial". Pendekatan analisis wacana kritis ini bukan hanya didasarkan pada analisis teks, melainkan juga harus dilihat bagaimana teks tersebut dapat diproduksi, sehingga diperoleh suatu pengetahuan mengapa dapat diperoleh teks seperti itu.

Wacana oleh Van Dijk dikutip Fauzan (2014) digambarkan mempunyai tiga dimensi yaitu teks, kognisi sosial, dan konteks sosial dan ketiga dimensi wacana tersebut digabungkan menjadi suatu kesatuan untuk analisis. Dalam dimensi teks, yang dianalisis adalah struktur teks dan strategi wacana digunakan untuk memperjelas tema yang dibuat. Dimensi kognisi sosial menganalisis proses memperoleh teks berita yang melibatkan kognisi individu dari orang lain. Dimensi konteks sosial menganalisis kerangka wacana yang berkembang di khalayak ramai akan suatu berita. 
Pendekatan analisis wacana kritis menurut Van Dijk, kerangka wacana terdiri atas tiga struktur yang membentuk satu kesatuan. Tiga struktur tersebut adalah struktur makro, super struktur, dan struktur mikro. Struktur makro merujuk pada semua makna yang ada pada tema atau topik dalam wacana. Super struktur merujuk pada skematika wacana yang lazim digunakan, yang dimulai dari pendahuluan, isi pokok, dan diakhiri dengan penutup/simpulan. Selanjutnya struktur mikro merujuk pada makna setempat, yaitu wacana dapat digali dari aspek semantik, sintaksis, stilistika, dan retorika setempat. Dari penjelasan di atas Van Dijk menyimpulkan bahwa kerangka wacana harus mempertimbangkan aspek makna universal yang dapat diperlihatkan melalui analisis struktur makro dan super struktur yang posisinya jauh di atas analisis kata dan kalimat, tetapi analisis struktur mikro tetap diperhitungkan. Dengan menganalisis keseluruhan komponen kerangka wacana, dapat dijelaskan kognisi sosial pembuat wacana. Dari pernyataan tersebut dapat disimpulkan bahwa cara memandang seseorang terhadap suatu yang ditulisnya dalam wacana akan menentukan ciri khas dan kerangka wacana yang dituliskan.

\section{(4) Analisisis Wacana Kritis Ruth Wodak (Discourse-Historica Approaches/DHA)}

Pendekatan analisis wacana kritis yang dikemukakan oleh Wodak dikutip Fauzan (2014), yaitu untuk melakukan analisis pada sebuah wacana adalah dengan cara melihat faktor historis dalam suatu wacana. Pendekatan analisis wacana kritis yang dikembangkan itu disebut pendekatan historis wacana karena dalam menganalisis wacana harus menyertakan konteks histori untuk menjelaskan suatu kelompok atau komunitas tertentu.

Pendekatan analisis wacana kritis yang dikemukakan Wodak dapat dilakukan tiga cara: (1) menentukan topik utama dari sebuah wacana yang spesifik; (2) melakukan telaah strategi-strategi diskursif (termasuk strategi argumentasi); dan (3) menganalisis makna-makna yang nyata dalam kebahasaan, juga makna-makna kebahasaan dalam bentuk lain. Beberapa elemen dan strategi diskursif yang harus mendapatkan perhatian menurut Wodak dalam menganalisis wacana kritis adalah sebagai berikut.

a. Bagaimana pembuatan nama orang dan mengacu kepada siapa?

b. Bagaimana sifat, watak, kualitas, dan bentuk penggambaran kepada mereka?

c. Argumentasi seperti apakah orang atau sekelompok orang yang digambarkan secara eksklusi dan inklusi?

d. Dari pandangan manakah pelabelan, penggambaran, dan argumentasi disampaikan?

e. Pengungkapan apakah disampaikan dengan jelas, diintensifkan, atau malah 
dikurangi?

Dari pertanyaan-pertanyaan di atas, Wodak memilih 5 tipe strategi diskursif, yang kesemuanya menghadirkan citra diri sendiri yang positif dan untuk orang lain yang negatif.

\section{(5) Analisis Wacana Kritis Sara Mills (Feminist Stylistics Approach/FSA)}

Pendekatan analisis wacana kritis Sara Mills memfokuskan seperti apa perempuan dimunculkan dalam wacana. Selama ini perempuan selalu disingkirkan dan berada dalam keadaan yang tidak baik dan para perempuan itu tidak diberikan kesempatan untuk membela diri. Pendekatan wacana kritis ini sering disebut sebagai pendekatan analisis wacana perspektif feminis/feminist stylistics. Menurut Sara Mills yang dikutip Fauzan (2014), pendekatan perspektif feminis ini memiliki tujuan untuk menjelaskan apa yang ada dalam stilistika konvensional akan menjadi lebih jelas dalam menganalisis wacana. Hal ini akan memaksimalkan fungsi stilistika dalam analisis wacana bahwa apakah bahasa itu hanya sekedar ada atau memang harus ada dan dimunculkan.

Sara Mills mengembangkan pendekatan ini untuk mengamati seperti apa tampilan pelaku dalam wacana. Maksudnya, siapa yang akan menjadi subjek penceritaan dan siapa yang akan menjadi objek penceritaan. Dengan demikian, akan didapat seperti apa bangunan wacana dan makna yang bagaimana yang ada dalam wacana secara detailnya. Sara Mills juga mengamati seperti apa pembaca dan penulis diperlakukan dan bagaimana pembaca mengidentifikasi dan menempatkan dirinya dalam wacana. Hal ini akan menempatkan pembaca pada salah satu posisi dan mempengaruhi bagaimana wacana tersebut diwujudkan. Gaya penceritaan dan posisiposisi yang ditempatkan dan ditampilkan dalam wacana ini membuat satu pihak dilegalkan dan pihak lain tidak dilegalkan.

Selanjutnya Sara Mills membagi ke dalam tiga tingkatan untuk menganalisis wacana kritis, ketiga tingkatan tersebut adalah sebagai berikut.

(a) Tingkatan kata, yang meliput seksisme dalam bahasa dan seksisme maknanya.

(b) Tingkata frasa/kalimat, meliputi: penamaan, pelecehan pada wanita, belas kasihan, pengkerdilan, dan penghalusan.

(c) Tingkatan wacana, meliputi: karakter, peran, fragmentasi, vokalisasi, skemata.

\section{SIMPULAN}

Wacana adalah bahasa yang bermakna yang dapat berbentuk lisan, tulisan, dan simbol. Wujud dari bentuk wacana dapat berupa: (1) teks, berupa pengumuman, karangan, makalah, skripsi, roman, dsb; (2) ucapan, berupa percakapan, tanya jawab, dialog, dsb; (3) lakon, berupa drama, 
sinetron, puisi, atraksi, dsb; (4) artefak, berupa bangunan, alat-alat batu, logam , puing, dsb. Wacana yang telah dibuat dapat dikritisi dan dianalisis oleh orang lain yang biasa disebut analisis wacana kritis.

Analisis wacana kritis adalah studi linguistik yang membahas wacana bukan dari unsur kebahasaan, melainkan mengaitkannya dengan konteks. Dasar teoretis analisis wacana didasarkan pada beberapa perkembangan sejarah dalam filsafat pengetahuan dan teori sosial. Oleh karena itu, faktor histori, sosial, dan ideologi adalah sumber utama dalam kerangka kerja analisis wacana kritis. Adapun tujuan utama analisis wacana kritis adalah membuka kesamaran yang ada dalam wacana.

Untuk menganalisis wacana kritis, ada beberapa pendekatan yang disampaikan para ahli. Pertama, pendekatan analisis wacana kritis Norman Fairclough menjelaskan bahwa kegiatan berwacana sebagai praktik sosial yang menyebabkan ada hubungan dialektikal antara praktik sosial dan proses terbentuknya wacana, yaitu wacana mempengaruhi tatanan sosial dan tatanan sosial mempengaruhi wacana. Kedua, pendekatan analisis wacana kritis yang dibuat Van Leeuwen menjelaskan bagaimana orang-orang tertentu dan aktor sosial (social actors) dimunculkan dalam wacana. Bagaimana suatu kelompok yang mendominanasi lebih memegang kendali dan kelompok yang posisinya rendah digambarkan sebagai orang yang tidak baik. Ketiga, pendekatan analisis wacana kritis yang dikemukan oleh Van Dijk, yaitu pendekatan kognitif sosial yang bukan hanya didasarkan pada analisis bahasa wacana, melainkan juga harus dilihat bagaimana wacana tersebut diproduksi dan mengapa dapat diperoleh wacana seperti itu. Dijelaskan dalam pendekatan ini bahwa sesuatu yang ditulis seseorang dalam wacana akan menentukan ciri khas dan kerangka wacana yang dituliskan. Keempat, pendekatan analisis wacana kritis yang disampaikan Wodak adalah pendekatan wacana historis yang menjelaskan bahwa untuk melakukan analisis pada sebuah wacana dengan cara melihat faktor historis dalam suatu wacana itu. Kelima, pendekatan analisis wacana kritis Sara Mills adalah perspektif feminis/feminist stylistics yang memfokuskan seperti apa perempuan dimunculkan dalam wacana karena selama ini perempuan selalu disingkirkan dan berada dalam keadaan yang tidak baik dan para perempuan itu tidak diberikan kesempatan untuk membela diri. 


\section{DAFTAR RUJUKAN}

Alwi, Hasan,dkk. (2010). Tata Bahasa Baku Bahasa Indonesia. Jakarta: Balai Pustaka

Darma, Yoce, A. (2009). Analisis Wacana Kritis. Bandung: Yrama Widya

Eriyanto. (2001). Analisis Wacana, Pengantar Analisis Teks Media. LKiS: Yogyakarta

Fairclough, Norman. (1989). Language and Power. New York: Addison Wesley Longman.

Fauzan, Umar. (2014). Analisis Wacana Kritis dari Model Fairclough hingga Mills. Dalam Jurnal Pendidikan, Vol. 6 (1): $1-15$

Hamad, Ibnu. (2007). Lebih Dekat dengan Analisis Wacana. Jurnal Mediator. Vol.8 (2): $325--344$

Zaimar, Okke Kusuma Sumantri dan Ayu Basuki Harahap. (2009). Telaah Wacana. Jakarta: The Intercultural Institute 